\title{
Effects of Diabetes and of Injury on Muscle Protein in the Mouse, and Their Interaction
}

\author{
K. N. Frayn \\ M. R. C. Trauma Unit, University of Manchester, Manchester, England
}

\begin{abstract}
Summary. The effects of a $20 \%$ dorsal scald injury and of different severities of streptozotocin diabetes on hindquarter muscle protein have been studied in the mouse. Ten days after scald injury muscle protein contents were generally unaffected, whereas moderate diabetes $(200 \mathrm{mg}$ streptozotocin $/ \mathrm{kg}$ body weight; plasma glucose concentrations $17-46 \mathrm{mmol} / \mathrm{l}$; normal $11 \mathrm{mmol} / \mathrm{l}$ ) led to net loss of muscle protein. Production of scald injury in the moderately diabetic mouse caused significant additional loss of muscle protein, especially from the extensor digitorum longus. Milder diabetes (maximum plasma glucose concentration $15 \mathrm{mmol} / \mathrm{l}$ ) did not lead to loss of muscle protein. However, scald injury in the mildly diabetic mouse caused significant loss of protein from all muscles studied. The effects of diabetes and of injury on loss of muscle protein were at least additive and in some muscles probably synergistic.
\end{abstract}

Key words: Glucose, insulin, muscle protein, scald injury, streptozotocin diabetes

Loss of muscle protein has long been recognised as a feature of uncontrolled diabetes mellitus [1]. Muscle wasting is also seen after injury, and particularly in burned patients [2]. However, although many diabetic patients suffer surgical or accidental trauma, the effect of the combination of these conditions has received little attention except with regard to early circulatory changes [3] and wound healing [4, 5]. Most textbooks on diabetes cover the management of surgical patients, and state that more insulin is required in 'stress' states such as infection or trauma $[6,7]$, but this empirical advice is based mainly on measurements of blood glucose concentrations. In view of the paucity of data the interaction of diabetes and injury with respect to muscle protein metabolism has been studied using the mouse as an experimental model.

\section{Methods}

Male albino mice weighing initially $27-33 \mathrm{~g}$ were kept at $20^{\circ} \mathrm{C}$ with $12 \mathrm{~h}$ light per day, and were fed ad libitum throughout on Labsure CRM nuts (The Christopher Hill Group Ltd., Poole, U.K; protein content $17.5 \%$ ). Diabetes was induced with a single IV injection of streptozotocin in citrate buffer $(0.1 \mathrm{mmol} / \mathrm{l} ; \mathrm{pH} 4.5)$. All non-diabetic animals were injected with buffer alone. Injections were given under brief ether anaesthesia. In experiments involving injury, 3-4 days after injection some mice were given a $20 \%$ body surface area full skin thickness dorsal scald injury [8] under ether anaesthesia; non-injured animals were also anaesthetised and had their dorsal fur clipped. Mice injected with buffer only and not scalded are referred to as 'untreated'.

Mice were killed by cervical dislocation at various times after treatment and a blood sample taken from the chest for measurement of plasma glucose and insulin concentrations [9]. The combined left and right hindquarters were skinned and isolated by severing the trunk at the level of the iliac crests and removing the pelvic contents, genitalia and tail. Feet were removed at the ankie joints. Superficial fat was removed. The soleus (a mainly red muscle) and the plantaris or extensor digitorum longus (intermediate muscles) were removed from each leg, and bilateral muscles dissolved together in $\mathrm{NaOH}(1 \mathrm{ml} ; 1 \mathrm{~mol} / \mathrm{l})$. The remainder of the hindquarters was dissolved in hot $\mathrm{NaOH}(\mathrm{ca} .8 \mathrm{ml} ; 10 \mathrm{~mol} / 1)$, filtered through glass wool to remove bones, and made up to $500 \mathrm{ml}$ with water. Total protein contents were measured on these solutions by the method of Lowry et al. [10]. The results for soleus and extensor digitorum longus were added to those for the remaining hindquarters to give a figure for total hindquarter protein. The contribution of collagen to this estimate was $10-12 \%$ as measured by hydroxyproline estimation [11] after hydrolysis of samples in $\mathrm{HCl}(6 \mathrm{~mol} / \mathrm{l})$ at $110^{\circ} \mathrm{C}$ overnight.

Food intake was measured in separate experiments. From 3 to 7 mice were kept together in each cage after treatment. The normal food was powdered so as to pass through a sieve. A weighed amount was provided in a metal pot with an outer surrounding dish. Little if any food was scattered outside the outer dish. Each 
day the contents of the pot and dish were removed and fresh food provided. Faeces and sawdust were removed from the contents by sieving and hand-picking and the remaining food was dried to constant weight (overnight) at $70^{\circ} \mathrm{C}$ to minimise contamination by urine. Samples of unused food were also dried to determine their volatile water content $(9.1 \% \mathrm{w} / \mathrm{w})$. Water consumption was measured by weighing the water bottles each day. The combined weight of the mice in the cage was used to calculate the consumption in grams of food or $\mathrm{ml}$ of water per $100 \mathrm{~g}$ body weight.

Statistical methods were those described by Snedecor \& $\mathrm{Co}-$ chran [12]. Body weights, plasma glucose concentrations and muscle protein contents are shown as mean values \pm SEM. Plasma insulin concentrations were non-normally distributed and median values with ranges are shown; food and water consumption are

Table 1. Food and water consumption in scalded, diabetic and diabetic scalded mice

\begin{tabular}{|c|c|c|c|c|}
\hline & $\begin{array}{l}\text { Un- } \\
\text { treated }\end{array}$ & Scald & $\begin{array}{l}\text { Strepto- } \\
\text { zotocin } \\
(200 \mathrm{mg} / \\
\mathrm{kg})\end{array}$ & $\begin{array}{l}\text { Strepto- } \\
\text { zotocin } \\
(200 \mathrm{mg} / \\
\mathrm{kg}) \\
\text { and } \\
\text { scald }\end{array}$ \\
\hline No. of mice & 10 & 4 & 12 & 12 \\
\hline No. of cage-nights & 9 & 6 & 12 & 24 \\
\hline $\begin{array}{l}\text { Food consumption } \\
\mathrm{g} / 100 \mathrm{~g} \text { body wt. }\end{array}$ & $\begin{array}{l}12 \\
(7-14)\end{array}$ & $\begin{array}{l}12 \\
(8-15)\end{array}$ & $\begin{array}{l}15 \\
(13-17)\end{array}$ & $\begin{array}{l}16 \\
(8-22)\end{array}$ \\
\hline $\begin{array}{l}\text { Water consumption } \\
\mathrm{ml} / 100 \mathrm{~g} \text { body } \mathrm{wt} \text {. }\end{array}$ & $\begin{array}{l}13 \\
(8-16)\end{array}$ & $\begin{array}{l}19 \\
(13-23)\end{array}$ & $\begin{array}{l}53 \\
(39-63)\end{array}$ & $\begin{array}{l}38 \\
(15-85)\end{array}$ \\
\hline
\end{tabular}

Results were calculated for each cage (3-7 mice) for each night and are shown as medians with ranges also shown in this way. Wilcoxon's 2-sample rank test was used to determine the significance of differences between groups. Leastsquares methods were used for correlations and regressions except when plasma insulin concentrations were involved, when Kendall's rank correlation method was used.

\section{Experimental Design}

In experiments on the combination of scald injury with diabetes two different severities of diabetes were studied, induced with either $200 \mathrm{mg} / \mathrm{kg}$ or $125 \mathrm{mg} / \mathrm{kg}$ streptozotocin. As previous experiments had shown that there were significant differences between batches of animals in the mean total protein contents of various muscles, all four types of treatment were studied for each part of the experiment. Comparisons have therefore been made only between treatments within each batch of animals.

\section{Results}

\section{General Effects of Diabetes and of Injury}

No ketonuria was detected in any animal when tested (Keto-Diastix; Ames Co., U. K.) at the time of killing. No mice died from the diabetes alone. After scalding there was $10 \%$ mortality (6/62), similar to that observed previously $[8,9]$, all deaths occurring within $48 \mathrm{~h}$ of injury. Diabetes did not affect the mortality rate.

Food intake was not decreased in the diabetic and diabetic injured animals compared with the untreated group (Table 1).

Table 2. Effects of moderate diabetes, of scald injury and of their combination in the mouse

\begin{tabular}{|c|c|c|c|c|}
\hline & \multicolumn{4}{|l|}{ Treatment } \\
\hline & $\begin{array}{l}1 \\
\text { Untreated }\end{array}$ & $\begin{array}{l}2 \\
\text { Scald }\end{array}$ & $\begin{array}{l}3 \\
\text { Streptozotocin } \\
(200 \mathrm{mg} / \mathrm{kg})\end{array}$ & $\begin{array}{l}4 \\
\text { Streptozotocin } \\
(200 \mathrm{mg} / \mathrm{kg}) \\
\text { and scald }\end{array}$ \\
\hline Number & 11 & 10 & 11 & 8 \\
\hline Initial weight $(\mathrm{g})$ & $30.2 \pm 0.3$ & $30.7 \pm 0.3$ & $30.8 \pm 0.2$ & $30.4 \pm 0.4$ \\
\hline Final weight $(\mathrm{g})$ & $33.4 \pm 0.4$ & $31.8 \pm 0.5^{\mathrm{a}}$ & $26.7 \pm 0.7^{\text {aaa }}$ & $26.6 \pm 0.7^{\text {aaa }}$ \\
\hline $\begin{array}{l}\text { Plasma concentration } \\
\text { Glucose }(\mathrm{mmol} / \mathrm{l}) \\
\text { Insulin }(\mathrm{ng} / \mathrm{ml})\end{array}$ & $\begin{aligned} 11.3 \pm 0.4 \\
2.3(1.0-7.0)\end{aligned}$ & $\begin{array}{l}11.3 \pm 0.3 \\
1.4(0.0-4.0)\end{array}$ & $\begin{array}{l}31.6 \pm 2.0^{\mathrm{aaa}} \\
0.3(0.0-2.4)^{\mathrm{aaa}}\end{array}$ & $\begin{aligned} 28.7 & \pm 2.4^{\text {aаa }} \\
0.9 & (0.4-1.9)^{\text {аa }}\end{aligned}$ \\
\hline $\begin{array}{l}\text { Total protein }(\mathrm{mg}) \\
\text { Hindquarters } \\
\text { Soleus } \\
\text { E.d.1. }\end{array}$ & $\begin{array}{c}425 \pm 14 \\
2.05 \pm 0.07 \\
2.82 \pm 0.07\end{array}$ & $\begin{array}{l}398 \pm 11 \\
1.83 \pm 0.07^{\mathrm{a}} \\
2.83 \pm 0.08\end{array}$ & $\begin{array}{l}346 \pm 10^{\text {aaa }} \\
1.99 \pm 0.06 \\
2.78 \pm 0.11\end{array}$ & $\begin{array}{l}320 \pm 9^{\text {aaa }} \\
1.75 \pm 0.07^{\text {aa. bb }} \\
2.37 \pm 0.05^{\text {aaa. bb }}\end{array}$ \\
\hline
\end{tabular}

Protein contents refer to the combined bilateral muscles; e.d.l. = extensor digitorum longus. Insulin concentrations are shown as median values with ranges in parentheses. Significance of differences between groups:

difference from untreated group: ${ }^{a} \mathrm{p}<0.05$, ${ }^{\text {aa }} \mathrm{p}<0.02$, aaa $\mathrm{p}<0.002$

difference between groups 3 and $4:{ }^{\mathrm{b}} \mathrm{p}<0.05,{ }^{\mathrm{bb}} \mathrm{p}<0.02$, ${ }^{\mathrm{bbb}} \mathrm{p}<0.002$

Differences between groups 2 and 4 are discussed in. the text 


\section{Effects of Diabetes on Muscle Protein}

Six mice were given streptozotocin in doses of up to $220 \mathrm{mg} / \mathrm{kg}$, and killed 7 days later. Plasma glucose concentrations ranged from about normal (see Table 2) to $26 \mathrm{mmol} / 1$ (Fig. 1). The protein contents of the soleus, plantaris and the combined muscle group were obviously decreased at plasma glucose concentrations of $20 \mathrm{mmol} / \mathrm{l}$ and higher (Fig. 1). In each case there was a significant negative correlation between total protein content and plasma glucose load.

\section{Effects of Scald Injury and Diabetes}

Two severities of diabetes were studied in these experiments. Mice were killed 10 days after scalding or clipping.

Moderate Diabetes. After $200 \mathrm{mg} / \mathrm{kg}$ streptozotocin (Table 2) body weights fell similarly in both diabetic and diabetic injured mice, but were stable by the time of killing. Plasma glucose concentrations in the diabetic mice ranged from $17-46 \mathrm{mmol} / \mathrm{l}$, whereas scald injury alone had no effect on plasma glucose concentration. Plasma insulin concentrations were reduced in both groups of diabetic mice.

The total protein content of the hindquarters was significantly decreased in the diabetic non-injured animals compared with the untreated, although the protein contents of soleus and extensor digitorum longus were not significantly reduced. In contrast, scald injury alone had little effect on muscle protein contents. However, in the diabetic injured mice the protein contents of soleus, extensor digitorum longus and the complete hindquarters were all very significantly decreased compared with the untreated mice and were also, except in the case of the soleus, significantly decreased $(p<0.002)$ compared with nondiabetic injured mice; that is, diabetes and injury produced significantly greater loss of muscle protein than injury alone. In addition the muscle protein contents in the injured diabetic mice were lower than those in the non-injured diabetic, very significantly so in the case of the extensor digitorum longus. For the hindquarters this was shown by the significant depression of the regression line of muscle protein on plasma glucose concentration (Fig. 2).

Mild Diabetes. Since the effects of diabetes induced with $200 \mathrm{mg} / \mathrm{kg}$ were generally much more pronounced than those of injury, any additive effects might have been masked. In further experiments milder diabetes was therefore induced $(125 \mathrm{mg} / \mathrm{kg}$ streptozotocin) (Table 3). Body weights fell less rapidly than with the higher dose of streptozotocin

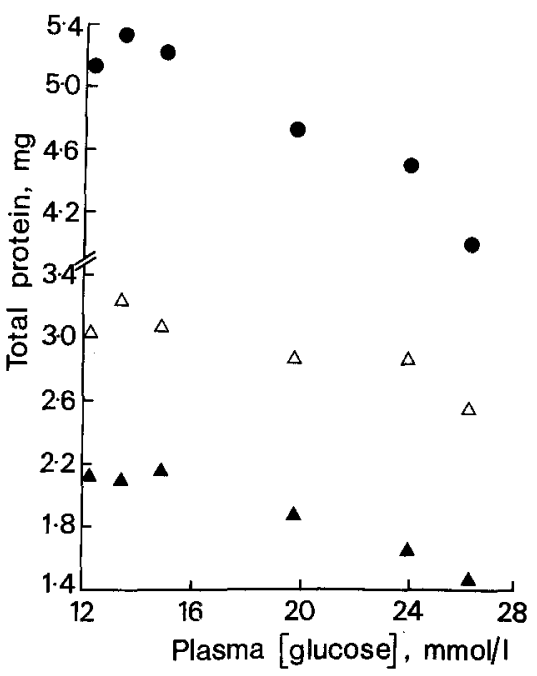

Fig. 1. Effect of diabetes on muscle protein content. Seven days after injection of streptozotocin (180-220 $\mathrm{mg} / \mathrm{kg}$ IV) mice were killed and the total protein contents of the combined bilateral soleus $(\Delta)$ and plantaris $(\Delta)$ muscles measured, together with the plasma glucose concentration. The sum of these protein contents is also shown ( $\bullet$ ). The regression of total protein on plasma glucose concentration was significant in each case $(r=-0.98, p<0.001$; $\mathrm{r}=-0.87, \mathrm{p}<0.05 ; \mathrm{r}=-0.96, \mathrm{p}<0.01$ respectively

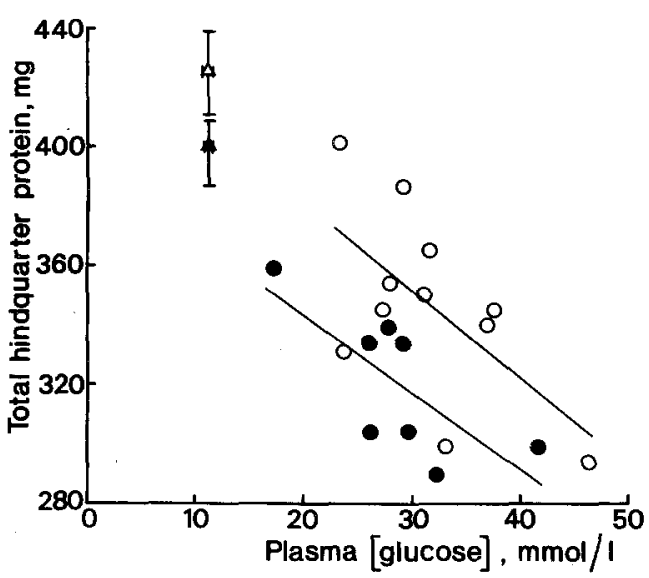

Fig. 2. Reduction in muscle protein content in injured diabetic mice. Mice were killed 14 days after injection of streptozotocin $(200 \mathrm{mg} / \mathrm{kg}$ IV); some (•) had had a $20 \%$ dorsal scald injury 4 days after injection, others $(O)$ not. The regressions of total hindquarter protein content on plasma glucose concentration were significant in each group $(\mathrm{r}=-0.73, \mathrm{p}<0.05 ; \mathrm{r}=-0.62, \mathrm{p}<0.05$ respectively). The slopes of the lines were not significantly different but the regression line for the injured diabetic mice was significantly depressed compared with that for the non-injured group $(p<0.01$ by analysis of covariance). Results in untreated $(\Delta)$ and in non-diabetic injured (ム) mice are also shown, as means \pm SEM

and in the non-injured animals were tending to increase again at 10 days after treatment ( 2 weeks after injection). Plasma glucose concentrations were slightly elevated compared with untreated animals in 
Table 3. Effects of mild diabetes, of scald injury and of their combination in the mouse

\begin{tabular}{|c|c|c|c|c|}
\hline & \multicolumn{4}{|l|}{ Treatment } \\
\hline & $\begin{array}{l}1 \\
\text { Untreated }\end{array}$ & $\begin{array}{l}2 \\
\text { Scald }\end{array}$ & $\begin{array}{l}3 \\
\text { Streptozotocin } \\
(125 \mathrm{mg} / \mathrm{kg})\end{array}$ & $\begin{array}{l}4 \\
\text { Streptozotocin } \\
(125 \mathrm{mg} / \mathrm{kg}) \\
\text { and scald }\end{array}$ \\
\hline Number & 7 & 10 & 8 & 10 \\
\hline Initial weight $(\mathrm{g})$ & $30.0 \pm 0.5$ & $30.3 \pm 0.5$ & $30.3 \pm 0.5$ & $29.2 \pm 0.4$ \\
\hline Final weight $(\mathrm{g})$ & $30.6 \pm 0.7$ & $27.6 \pm 0.6^{\mathrm{aa}}$ & $29.3 \pm 0.6$ & $27.9 \pm 0.8^{\mathrm{a}}$ \\
\hline \multicolumn{5}{|l|}{ Plasma concentrations } \\
\hline Glucose (mmol/l) & $11.3 \pm 0.4$ & $11.1 \pm 0.5$ & $12.9 \pm 0.5^{\mathrm{a}}$ & $11.9 \pm 0.4$ \\
\hline Insulin $(\mathrm{ng} / \mathrm{ml})$ & $1.7(1.1-3.0)$ & $1.6(0.7-4.2)$ & $2.4(1.3-3.8)$ & $1.6(0.7-8.3)$ \\
\hline \multicolumn{5}{|l|}{ Total protein $(\mathrm{mg})$} \\
\hline Hindquarters & $354 \pm 10$ & $332 \pm 13$ & $345 \pm 11$ & $282 \pm 8^{\text {aaa. bbb }}$ \\
\hline Soleus & $2.22 \pm 0.08$ & $2.04 \pm 0.07$ & $2.11 \pm 0.07$ & $1.91 \pm 0.06^{\mathrm{aa}, \mathrm{b}}$ \\
\hline E.d.l. & $3.22 \pm 0.09$ & $3.13 \pm 0.13$ & $3.25 \pm 0.09$ & $2.95 \pm 0.09^{\mathrm{b}}$ \\
\hline
\end{tabular}

Conventions are as in the footnote to Table 2

Table 4. Comparison of the effects of diabetes and scald injury separately with those of their combination on muscle protein in the mouse

\begin{tabular}{|c|c|c|c|c|}
\hline \multirow{3}{*}{ Muscle } & \multicolumn{4}{|c|}{ Mean loss of mucle protein ( $\%$ of untreated) } \\
\hline & \multirow[t]{2}{*}{ Scald } & \multirow[t]{2}{*}{ Diabetes } & \multicolumn{2}{|c|}{ Scald + Diabetes } \\
\hline & & & Expected & Observed \\
\hline Hindquarter & 6.4 & 18.6 & 23.8 & 24.7 \\
\hline Soleus & 10.4 & 2.9 & 13.0 & 14.6 \\
\hline E.d.1. & -0.4 & 1.4 & 1.1 & 15.8 \\
\hline Hindquarter $^{\mathrm{a}}$ & 6.2 & 2.5 & 8.6 & 20.3 \\
\hline Soleus ${ }^{\mathrm{a}}$ & 8.5 & 5.0 & 13.0 & 14.2 \\
\hline E.d. $1^{a}{ }^{a}$ & 2.9 & -0.9 & 2.0 & 8.6 \\
\hline
\end{tabular}

a Based on results in Table 3 (diabetes induced with streptozotocin $125 \mathrm{mg} / \mathrm{kg}$ ); otherwise based on results in Table 2 (streptozotocin $200 \mathrm{mg} / \mathrm{kg}$ ). Loss of muscle protein refers to the percentage difference between treated and untreated groups. The expected loss due to the combined treatments was calculated from the product of the fractions remaining after the individual treatments

the diabetic non-injured group but in the injured group there was no significant hyperglycaemia. Plasma insulin concentrations in the diabetic animals were not significantly reduced at this stage compared with the non-diabetic group. There was a significant positive correlation between plasma glucose and insulin concentrations in the non-injured diabetic mice $(\mathrm{r}=0.57 ; \mathrm{p}<0.05)$.

With this milder degree of diabetes there were no significant changes in muscle protein content in the diabetic non-injured mice compared with the untreated, and as before injury alone had no effect on muscle protein contents. However, in the injured diabetic mice there was significant depression of muscle protein contents compared both with the untreated animals and also with the non-injured diabetic, despite the more severe diabetes (as judged by hyperglycaemia) in the latter group. The hindquarter protein content was also significantly depressed $(p<0.01)$ compared with injured non-diabetic animals.

To test whether the effects of injury and of diabetes on loss of muscle protein were additive, the percentage differences in mean values in each group from those in untreated animals were calculated (Table 4). In all six cases the observed loss in the injured diabetic mice was greater than the combined effects of the individual treatments $(\mathrm{p}<0.05$ by sign test). This synergism appeared to occur more in white muscle, e.g. extensor digitorum longus, than in red muscle, e.g. soleus.

\section{Discussion}

Although loss of muscle mass was a characteristic feature of diabetes mellitus before the introduction of insulin treatment [1], this aspect of diabetes has not received much attention experimentally. Several studies have shown a depression in the rate of muscle protein synthesis in experimental diabetes [13, 14], but apart from the loss of protein from the mouse soleus noted by Le Marchand-Brustel and Freychet [15] it has been difficult to demonstrate a net fall in muscle protein content. This has been attributed to a protective effect of activity on certain hindlimb muscles [14]. In the present experiments the use of the combined hindquarter muscles as an index of mixed 
muscle types may have helped to overcome this problem. Another difficulty is that the changes induced by diabetes of 'moderate' severity (see below) are small compared with the variation seen between batches of animals (Tables 2 and 3), so that comparisons between treatments must be made within a particular batch as in the present study. This variation is in keeping with that found in many aspects of protein metabolism $[14,16]$ and also with the differences in growth rate found between the batches of animals used in this study; others have shown that such differences in growth rate between groups of animals are related to differences in their rates of muscle protein synthesis [17].

The results show that the loss of muscle protein in diabetes is related to the severity of the disease (Figs. 1 and 2). Although lack of the direct stimulatory effect of insulin on muscle protein metabolism $[9,13]$ was probably the major cause of this loss, decreased insulin-stimulation of glucose utilisation may have contributed since glucose is also a regulator of protein metabolism in muscle [16]. After the smaller dose of streptozotocin there was no relationship between muscle protein and plasma glucose or insulin concentrations measured at the time of killing. However, it seems likely that some animals were showing spontaneous recovery at this stage, as observed after low doses of streptozotocin in the rat [18]. The plasma glucose and insulin concentrations at this stage may therefore not reflect those prevailing for most of the experimental period.

The small animal (rat or mouse) is not normally very sensitive to the muscle protein loss which characterises the general response to injury. After scald injury the period of net muscle protein breakdown lasts only 2-3 days $[9,19]$, despite a prolonged period of elevated oxygen consumption in response to the energy demand for increased evaporation through the burned area $[19,20]$. In the present experiments this was confirmed, in that at 10 days after injury (Tables 2 and 3 ) muscle protein contents in injured non-diabetic mice differed little from those in the untreated animals. The most obvious aspect of the comparison of diabetes and injury was therefore the much greater effect of the former on muscle protein, although even the larger dose of streptozotocin produced diabetes which would only be classed as 'moderate' by experimental standards $[18,21]$, with no ketonuria, plasma insulin concentrations still detectable and no mortality even when untreated. This made the demonstration of additive effects of diabetes and injury difficult since the effects of the former outweighed those of the latter. However, using the smaller dose of streptozotocin the diabetes produced was so mild that the potentiation of the effects of injury by coexisting diabetes was more clearly seen.

It is probable that the main reason for this potentiation was insulin deficiency. The primary mode of action of streptozotocin is considered to be destruction of pancreatic B-cells [22]. It is unlikely that other anabolic hormones such as growth hormone or growth hormone-related factors would have been involved since growth hormone concentrations are if anything elevated in diabetes [23]. Malnutrition was not a factor since even the injured diabetic animals maintained at least a normal food intake (Table 1). These results thus further highlight the importance of insulin for the recovery of the injured patient, and add weight to clinical observations that prevention of post-traumatic nitrogen loss is best achieved, at least in the normally nourished patient, with carbohydrate infusions which stimulate insulin release [24] or by the addition of insulin itself $[25,26]$.

The additive or synergistic effects of these conditions may have some relevance for the diabetic patient who is injured. The results suggest that careful control of the diabetes may be important not just from the point of view of the plasma glucose concentration, but in speeding recovery, since recovery of muscle strength is the main determinant of the length of convalescence [27]. Confirmation of these results is, however, required in man.

Acknowledgements. I am grateful to Paula F. Maycock for excellent technical assistance.

\section{References}

1. Cahill GF Jr, Aoki TT, Marliss EB (1972) Insulin and muscle protein. In: Freinkel N, Steiner DF (eds) Handbook of physiology, Section 7, vol 1. American Physiological Society, Washington DC, p 563-577

2. Kinney JM (1977) The metabolic response to injury. In: Richards JR, Kinney JM (eds) Nutritional aspects of care in the critically ill. Churchill Livingstone, Edinburgh London New York, p 95-133

3. Elebute EA, Little RA (1978) Effect of streptozotocin-diabetes on the local and general responses to injury in the rat. Clin Sci Mol Med 54: 431-437

4. Rosenthal S, Lerner B, Dibiase F, Enquist IF (1962) Relation of strength to composition in diabetic wounds. Surg Gynecol Obstet 115: 437-442

5. Herbsman H, Powers JC, Hirschman A, Shaftan W (1968) Retardation of fracture healing in experimental diabetes. $J$ Surg Res 8: 424-431

6. Pyke DA (1968) Management of diabetes in the presence of infection or injury. In: Oakley WG, Pyke DA, Taylor KW (eds) Clinical diabetes and its biochemical basis. Blackwell, Oxford Edinburgh, p 411-419

7. Wheelock FC Jr, Marble A (1971) Surgery and diabetes. In: Marble A, White P, Bradley RF, Krall LP (eds) Joslin's diabetes mellitus, 11th ed. Lea and Febiger, Philadelphia, p $599-620$ 
8. Frayn KN, Le Marchand-Brustel Y, Freychet P (1978) Studies on the mechanism of insulin resistance after injury in the mouse. Diabetologia 14: 337-341

9. Frayn KN, Maycock PF (1979) Regulation of protein metabolism by a physiological concentration of insulin in mouse soleus and extensor digitorum longus muscles. Effects of starvation and scald injury. Biochem $\mathbf{J}$ 184: 323-330

10. Lowry OH, Rosebrough NJ, Farr AL, Randall RJ (1951) Protein measurement with the Folin phenol reagent. J Biol Chem 193: $265-275$

11. Stegemann H, Stalder K (1967) Determination of hydroxyproline. Clin Chim Acta 18: 267-273

12. Snedecor GW, Cochran WG (1967) Statistical methods, 6th ed. lowa State University Press, Ames

13. Rannels DE, McKee EE, Morgan HE (1977) Regulation of protein synthesis and degradation in heart and skeletal muscle. In: Litwack G (ed) Biochemical actions of hormones, vol 4. Academic Press, New York San Francisco London, p 135-195

14. Millward DJ, Garlick PJ, Nnanyelugo DO, Waterlow JC (1976) The relative importance of muscle protein synthesis and breakdown in the regulation of muscle mass. Biochem $\mathbf{J}$ 156: $185-188$

15. Le Marchand-Brustel Y, Freychet P (1979) Effect of fasting and streptozotocin diabetes on insulin binding and action in the isolated mouse soleus muscle. J Clin Invest 64: 1505-1515

16. Fulks RM, Li JB, Goldberg AL (1975) Effects of insulin, glucose and amino acids on protein turnover in the rat diaphragm. J Biol Chem 250: 290-298

17. Garlick PJ, Millward DJ, James WPT (1973) The diurnal response of muscle and liver protein synthesis in vivo in mealfed rats. Biochem $J$ 136: 935-945

18. Junod A, Lambert AE, Stauffacher W, Renold AE (1969) Diabetogenic action of streptozotocin: relationship of dose to metabolic response. J Clin Invest 48: 2129-2139

19. Threlfall CJ, Little RA, Frayn KN (1980) The post-scald metabolic response in the growing rat. Evidence for a transient phase of muscle protein breakdown. Burns 7: 25-32

20. Caldwell FT, Osterholm JL, Sower ND, Moyer CA (1959) Metabolic response to thermal trauma of normal and thyro- privic rats at three environmental temperatures. Ann Surg 150: 976-988

21. Schein PS, Alberti KGMM, Williamson DH (1971) Effects of streptozotocin on carbohydrate and lipid metabolism in the rat. Endocrinology 89: 827-834

22. Rerup CC (1970) Drugs producing diabetes through damage of the insulin-secreting cells. Pharmacol Rev 22: 485-518

23. Johansen K, Hansen AP (1971) Diurnal serum growth hormone levels in poorly and well-controlled juvenile diabetics. Diabetes 20: 239-245

24. Elwyn DH, Gump FE, Iles M, Long CL, Kinney JM (1978) Protein and energy sparing of glucose added in hypocaloric amounts to peripheral infusions of amino acids. Metabolism 27: 325-331

25. Hinton P, Allison SP, Littlejohn S, Lloyd J (1971) Insulin and glucose to reduce catabolic response to injury in burned patients. Lancet I: 767-769

26. Burke JF, Wolfe RR, Mullany CJ, Mathews DE, Bier DM (1979) Glucose requirements following burn injury. Parameters of optimal glucose infusion and possible hepatic and respiratory abnormalities following excessive glucose intake. Ann Surg 190: 274-285

27. Carswell SH, Walker WF (1977) Exercise tolerance in surgical patients. In: Richards JR, Kinney JM (eds) Nutritional aspects of care in the critically ill. Churchill Livingstone, Edinburgh London New York, p 161-176

Received: July 11, 1980

K. N. Frayn, Ph. D.

M.R.C. Trauma Unit

Stopford Building

University of Manchester

Oxford Road

Manchester M13 9PT

England 